\section{The Fishes}

By Dr. Url Lanham. Pp. $116+24$ plates (New York and London: Columbia University Press, 1962.) 5 dollars; $40 s$.

T a lower price this book could fill an empty A niche by providing an introduction to fishes, written in the broadest detail, specifically for those without any biological training and not wanting to dig deeply into the subject. The style is simple and lucid, but one cavils at such unnecessary 'simplifications' as 'Jaws were invented by one or more stocks of the jawless fish . . .", and "Fishes that evolved the first crude airfloats were, .... able to redesign the fins, ..."

Dr. Lanham touches on most aspects of ichthyology. There is a chapter each on the origin of fishes, on the evolution of the Agnatha, sharks, Dipnoi and bonyfishes, while many facets of anatomy, physiology and ecology are dealt with in five chapters. The two chapters on marine and freshwater fishes are, in effect, summaries of zoogeographical and distributional problems. Speciation is touched on in a chapter devoted to trout and other salmonids. Since all these subjects are covered in one hundred and nine elegantly printed pages, it will be realized that the scope of the book is limited. Nevertheless, it does admirably serve to introduce its subject and even give satisfactory answers to many of the questions asked by the general reader.

The underlying thesis of the book is an unusual one for a popular work, namely the importance of the swimbladder in determining major evolutionary steps and later anatomical and morphological trends within the vertebrates grouped as fishes. Many more advanced text-books have passed too lightly over this fundamental dichotomy in the history of the fishes. It is thus very regrettable that the section dealing with living lungfishes is so misleading, partly by the inclusion of factual errors and partly by loosely phrased statements which result in unsupportable implications.

One final complaint: there is no bibliography.

$$
\text { P. H. GREENWOOD }
$$

The Biology of Malayan Scolytidae and Platypodidae By F. G. Browne. (Malayan Forest Records, No. 22.) Pp. $x i+255+9$ plates. (Kuala Lumpur: Government Press, 1961.) 15 Malayan dollars.

THIS valuable contribution to tropical entomology is the work of a forest officer who spent some thirty years in Malaya and Sarawak. When Mr. Browne began his observations on the bark and ambrosia beetles, less than 10 per cent of the 435 species mentioned in this book were known to occur in Malaya and nearly 250 of them were completely unknown to science.

Part 1 occupies 56 pages and it includes an essential chapter of the habitat and the fauna and another on the general biology of the Scolytidae and Platypodidae. This second chapter explains, with numerous examples, the food and feeding habits, the social organization, the relationship with hosts, the enemies and the economic importance of these bark and ambrosia beetles, as well as the evolution of their general habits. It is very well written and will appeal to any student or worker in forest entomology.

Parts 2 and 3 are devoted to the bionomies of the Malayan species of the Scolytidae and Platypodidae respectively. The descriptions are detailed, well set out and supported by references. There are, of course, some gaps in the information, but with this book now available they should be easier to fill.

The appendixes contain not only a bibliography and an index to the beetles but also a summary of the species of actual or potential importance and an index to the host plants. The plates and line drawings are very good and add appreciably to the usefulness of this Malayan Forest Record.

Those who have been aware for many years of Mr. Browne's work in Malaya and Sarawak are very glad that he has recorded in book form his observations and the help he has received from other entomologists on these two families of beetles which are so important to the forester in the tropics. Mr. Browne has now turned his attention to West Africa, where he is in charge of the West African Timber Borer Research Unit.

C. J. Taylor

A Conspectus of Aphids as Vectors of Plant Viruses By J. S. Kennedy, M. F. Day and V. F. Eastop. Pp. iii +114. (London: Commonwealth Institute of Entomology, 1962.) 25s.

X ORKERS in the field of plant virus transmission will welcome the publication of an index of aphid-transmitted viruses and their vectors. This work is a compilation from the literature up to the end of 1960 and consists mainly of two alphabetical indexes. The first lists under each host plant all the recognized viruses that have been tested for transmissibility by aphids. The second is a reciprocal index of all the aphids which have been tested for virus transmission and includes not only the records of successful transmission but also the failures to secure transmission: these latter include many previously unpublished records. There is a bibliography of some 450 titles.

While recognizing that there are obvious gaps in our knowledge and possibly inherent biases in the kinds of information available, the authors have analysed the material they have collected in an attempt to test various hypotheses concerning virus-vector relationships. This work undoubtedly points the way for future investigations and in systematizing this large body of information the authors have produced a work which will be an invaluable reference. BRUCE JoHNson

\section{The Classical Theory of Fields}

By L. D. Landau and E. M. Lifshitz. Translated from the Russian by Morton Hamermesh. (Course of Theoretical Physics. Vol. 2). Pp. ix +404 . (London, Oxford, Paris and Frankfurt : Pergamon Press, 1962 revised second edition.) $80 s$.

THIS is the second English edition of the book originally published in 1948 in the U.S.S.R. The present edition is substantially the same as that of the earlier English edition published in 1951, although there has been some re-arrangement of the subject-matter. The principal change is the addition of a chapter on cosmological problems which is somewhat uncritical and unselective in its approach. Quite properly there is a reference to the solutions of the gravitational equations at first found by Friedmann in 1922, but the names of de Sitter and Lemaitre do not appear.

A number of additional exercises has also been added in the present volume, which gives a very readable introduction to the special and general theories of relativity and to electromagnetic theory and the theory of light.
G. TEMPLE 